\title{
ANALISA TEKNIS DAN EKONOMIS PEMILIHAN MANAJEMEN AIR BALLAS PADA KAPAL (SHIP BALLAST WATER MANAGEMENT) DI INDONESIA
}

\author{
Mohammad Sholikhan Arif ${ }^{1}$, Hesty Anita Kurniawati ${ }^{1}$, M. Nurul Misbah ${ }^{1}$ \\ ${ }^{1)}$ Teknik Perkapalan, Fakultas Teknologi Kelautan, Institut Teknologi Sepuluh Nopember, Indonesia \\ Email: ichan_narch@yahoo.co.id
}

\begin{abstract}
Abstrak
Peraturan yang mengatur dan manajemen dari air ballas dikeluarkan oleh IMO (International Maritime Organization) melalui konvensi Manajemen air ballas. Konvensi tersebut menyatakan bahwa organisme yang berbahaya terhadap lingkungan, kesehatan manusia, properti atau sumber daya merusak keanekaragaman hayati atau mengganggu pemanfaatan terhadap suatu area jika dilepaskan di air laut. Pemerintah Republik Indonesia mengeluarkan Peraturan Presiden No. 132 tahun 2015 mengenai pengesahan Konvensi internasional untuk pengendalian dan manajemen air ballas dan sedimen dari kapal 2004 (The International Convention for the control and management of ships ballast water and sediment's 2004). Penelitian ini bertujuan untuk menganalisa sejauh mana kesiapan Indonesia dalam ratifikasi peraturan (come into force) Ballast water Management serta dampak yang diakibatkan setelah peraturan tersebut diratifikasi. Metode yang dilakukan dalam penelitian ini menggunakan 3 pendekatan yaitu dari aspek hukum, aspek teknis dan aspek ekonomis. Hasil dari penelitian ini adalah Peraturan Pemerintah Nomor 21 Tahun 2010 tentang Perlindungan Lingkungan Maritim sebagai jabaran dari Undang-Undang Nomor 17 Tahun 2008 tentang Pelayaran, telah sejalan dengan Konvensi Internasional untuk Pengendalian dan Manajemen Air Ballas dan Sedimen dari Kapal, 2004 dan Undang-Undang Nomor 17 Tahun 1985 tentang pengesahan United Nations Convention on the LAW of the Sea (UNCLOS). Serta Penggunaan sistem manajemen air ballas untuk kapal di perairan Indonesia lebih efektif dan efisien menggunakan filtration + electrolysis
\end{abstract}

Kata kunci: Peraturan, air ballas, manajemen air ballas, IMO, Teknis, Ekonomis

\section{PENDAHULUAN}

Salah satu upaya pemerintah untuk mencegah penyebaran spesies asing yang bersifat invasive (invasive Alien Species ) atau yang biasa disebut dengan organisme dan pathogen akuatik yang berbahaya (Harmful Aquatic Organism and Pathogens) yaitu dengan cara mengendalikan dan manajemen dari air ballas dan sedimen kapal.

Peraturan yang mengatur dan manajemen dari air ballas dikeluarkan oleh IMO (International Maritime Organization) melalui konvensi Manajemen air ballas. Konvensi tersebut menyatakan bahwa organisme diatas yang berbahaya terhadap lingkungan, kesehatan manusia, properti atau sumber daya merusak keanekaragaman hayati atau mengganggu pemanfaatan terhadap suatu area jika dilepaskan di air laut.

Air ballas yang berfungsi sebagai penyeimbang dari kapal sekaligus menjadi media atau vector pembawa spesies asing yang berbahaya. Ketika air ballas diambil dari area tertentu dan dibuang di daerah lain, maka organisme pathogen yang ada di dalam air ballas juga ikut terbawa. Organisme yang berasal dari tempat asal yang berbeda dengan tempat air ballas dibuang biasanya dikenal dengan spesies asing. Hasil dari beberapa studi sebelumnya spesies asing tersebt mengakibatkan gangguan yang bersifat invasive terhadap spesies local atau terhadap keseimbangan ekosistem di area tersebut.

Terdapat 110 kapal berbendera Indonesia yang melakukan pelayaran ke luar negeri, jumlahnya 
lebih kecil dari kapal dari luar negeri yang melakukan pelayaran, singgah di pelabuhan di Indonesia (Perhubungan 2015). Pada tahun 2014 data dari Badan Pusat Statistik menunjukkan bahwa jumlah kunjungan kapal di pelabuhan Indonesia, yang diusahakan dan tidak diusahakan yakni 863.036 unit. Informasi ini menunjukkan bahwa potensi terjadinya penyalahgunaan pembuangan air ballas dari kapal kapal yang berbendera asing lebih besar dari pada kapal berbendera Indonesia sehingga pemberlakuan konvensi internasional untuk pengendalian dan manajemen air ballas dan sedimen pada kapal tahun 2004 sangat penting.

Di Indonesia permasalahan terhadap air balas pernah terjadi di Teluk Lampung pada tahun 2012, dimana ditemukan banyak spesies ikan yang tibatiba mati. Setelah diteliti hasil menunjukkan bahwa kejadian tersebut disebabkan oleh adanya organisme asing dari luar perairan Indonesia, yang masuk ke Teluk Lampung, yang dibawa oleh air ballas pada kapal. Oranisme asing yang terbawa oleh air ballas jika tidak dilakukan treatment yang baik bisa mengancam ekosistem laut.

Karena latar belakang diatas, pemerintah Republik Indonesia mengeluarkan Peraturan Presiden No. 132 tahun 2015 mengenai pengesahan Konvensi internasional untuk pengendalian dan manajemen air ballas dan sedimen dari kapal 2004 (The International Convention for the control and management of ships ballast water and sediment's 2004).

Indonesia berencana untuk meratifikasi Konvensi internasional untuk pengendalian dan manajemen air ballas dan sedimen dari kapal 2004 sehingga semua kapal yang ada di Indonesia wajib (enter into force) untuk menerapkan Ballast water management.

Penelitian ini bertujuan untuk menganalisa sejauh mana kesiapan Indonesia dalam penerapan peraturan Ballast water Management serta dampak yang diakibatkan setelah peraturan tersebut diratifikasi.

\section{TINJAUAN PUSTAKA}

\subsection{Sistem Ballas pada Kapal}

Cara kerja sistem ballast, secara umum adalah untuk mengisi tangki ballast yang berada di double bottom, dengan air laut, yang diambil dari seachest. Melalui pompa ballast, dan saluran pipa utama dan pipa cabang. Sistem ballast merupakan sistem untuk dapat memposisikan kapal dalam keadaan seimbang baik dalam keadaan trim depan maupun belakang, maupun keadaan oleng. Dalam perencanaannya adalah dengan memasukkan air sebagai bahan ballast agar posisi kapal dapat kembali pada posisi yang sempurna. Adapun omponen-komponen sistem ballas meliputi, sea chest, jalur pipa ballas, pipa yang melalui tangki, sistem perpipaan, pompa ballas, tangki ballas, jumlah dan jenis katup serta fitting, dan outboard.

\subsection{Invasi Biologis}

Hal yang perlu diwaspadai dari invasi biologis adalah bermacam macam vektor yang bertambah selama beberapa dekade terakhir, ketika beberapa laporan invasi yang dilaporkan pada beberapa abad ini. Air ballas menjadi "tersangka utama" dari kejadian penyebaran vekor invasi biologis [1]. Tabel berikut menunjukkan beberapa contoh dari spesies invasif yang ditransfer melalui air ballas kapal dan efeknya pada lingkungan.

Tabel 1. Dampak Organisme dari Air Ballas

\begin{tabular}{|l|l|l|l|}
\hline \multicolumn{1}{|c|}{ Organisme } & \multicolumn{1}{|c|}{ Asal } & Tempat terinvasi & \multicolumn{1}{|c|}{ Impacts } \\
\hline $\begin{array}{l}\text { Zebra Mussel } \\
\text { (Dreissena } \\
\text { polymorpha) }\end{array}$ & Eastern Europe & $\begin{array}{l}\text { Western/Nothem } \\
\text { Europe, North } \\
\text { America }\end{array}$ & $\begin{array}{l}\text { Menyumbat pipa asupan air, } \\
\text { mempengaruhi ekologi asli, } \\
\text { mempengaruhi irigasi. }\end{array}$ \\
\hline $\begin{array}{l}\text { North Pacific } \\
\text { Seastar } \\
\text { Asterias } \\
\text { amurensis) }\end{array}$ & Northern Pacific & $\begin{array}{l}\text { Southern } \\
\text { Australia }\end{array}$ & $\begin{array}{l}\text { reproduksiyang cepat, } \\
\text { mempengaruhi spesies asli }\end{array}$ \\
\hline $\begin{array}{l}\text { European Green } \\
\text { Crab (Carcinus } \\
\text { maenus) }\end{array}$ & Europe & $\begin{array}{l}\text { Southern } \\
\text { Australia, South } \\
\text { Africa, USA, } \\
\text { Japann }\end{array}$ & $\begin{array}{l}\text { Outcompete kepiting asli, sangat } \\
\text { invasif. }\end{array}$ \\
\hline $\begin{array}{l}\text { Mitten Crab } \\
\text { (Elocheir } \\
\text { sinensis) }\end{array}$ & Northern Asia & $\begin{array}{l}\text { Western Europe, } \\
\text { Baltic Sea, North } \\
\text { America }\end{array}$ & $\begin{array}{l}\text { Mempengaruhi kegiatan } \\
\text { penangkapan ikan, menyebabkan } \\
\text { erositepi sungai, mempengaruhi } \\
\text { spesies asli }\end{array}$ \\
\hline $\begin{array}{l}\text { Cholera(Vibrio } \\
\text { cholerae- various } \\
\text { strains) }\end{array}$ & $\begin{array}{l}\text { Various strains } \\
\text { with broad ranges }\end{array}$ & $\begin{array}{l}\text { South America, } \\
\text { Gulfof Mexico }\end{array}$ & epidemi kolera \\
\hline
\end{tabular}

Dari Tabel 1. diatas menunjukkan bahwa dampak organisme asing di suatu perairan dapat membahayakan ekosistem di wilayah tersebut.

\subsection{Pertukaran Air Ballas}

Sesuai dengan efektivitas dan jumlah teknologi treatment air ballas yang disetujui oleh IMO, IMO menghimbau kepada komunitas 
pelayaran untuk menggunakan pertukaran air ballas pada laut dalam selama pelayaran [2].

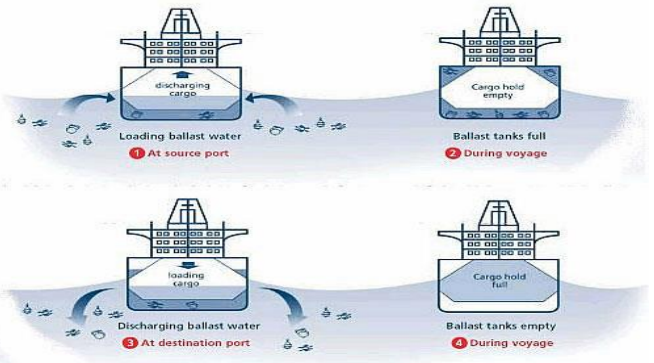

Gambar 1. Sistem Balas Kapal Menggunakan Air Laut

Seperti terlihat pada Gambar 1, bahwa ketika kapal-kapal barang seperti kapal kontainer atau tanker membongkar muatan, air laut dipompa ke dalam kompartemen di lambung kapal, sedang ketika mengangkut muatan, air laut di lambung kapal tadi dibuang ke laut. Air laut yang dipompakan ke lambung atau dibuang ke laut tadi berfungsi sebagai alat untuk menstabilkan dan menyeimbangkan kapal.

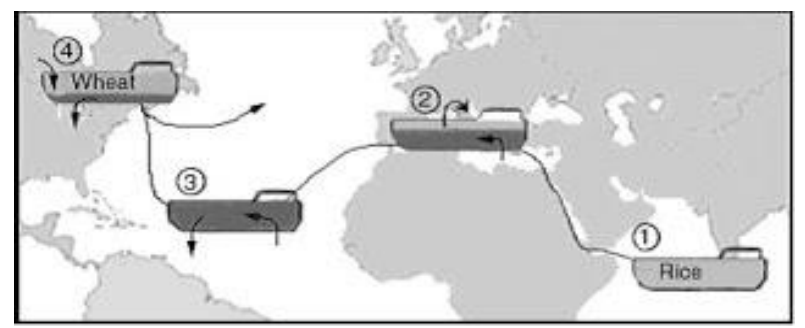

Gambar 2. Contoh pertukaran air balas di dunia.

Pada Gambar 2 mengilustrasikan lebih jelas tentang bagaimana pertukaran air balas terjadi. Sebuah kapal dari Lautan India berlayar melalui Terusan Suez, membongkar muatan di Mediterania sehingga kapal tersebut perlu mengisi tanki balas sebelum mengarungi Lautan Atlantic. Pertukaran air balas (ballast water exchange) terjadi di Lautan Atlantik sehubungan dengan akan masuk ke kawasan Great Lakes. Sehubungan dengan kapal mengangkut muatan terigu/gandum, maka air balas dibuang ke laut. Dari aktifitas yang digambarkan di atas, di seluruh dunia ada kurang lebih 10 milyar ton meter kubik air balas yang ditransfer kapal setiap tahunnya.

Permasalahannya, air tersebut mengandung ribuan spesies hewan laut maupun tanaman laut yang menimbulkan masalah bagi lingkungan laut, kesehatan manusia, serta mengancam ekonomi kelautan yang bergantung pada ekosistim laut yang sehat.

Persyaratan yang harus dipenuhi selama proses pertukaran air ballas diatur oleh IMO di bawah peraturan D-1 dari konvensi. disarankan untuk kapal untuk memiliki $95 \%$ pertukaran volume. Untuk metode sekuensial, kosong dan isi ulang dilakukan sedemikian rupa bahwa syarat di atas terpenuhi. Untuk mencapai pertukaran Volume $95 \%$ dalam aliran melalui metode dilusi, di bawah asumsi lengkap pencampuran, memompa tiga kali volume tangki ballas dianjurkan [3]. Selain itu, berdasarkan Peraturan B-4 Konvensi, IMO mendorong kapal untuk pertukaran air ballas setidaknya 200 mil laut jauh dari daratan terdekat dan pada kedalaman air minimal 200 meter. Jika kondisi di atas tidak dapat dipenuhi, kapal bisa naik ke 50 mil laut dari daratan terdekat, dan kedalaman air tidak boleh lebih rendah dari 200 meter [4].

Terdapat situasi tertentu dimana proses pertukaran air ballas tidak dapat dilakukan seperti berada di laut yang bergelombang tinggi, sehingga mengakibatkan ketika melakukan pertukaran air ballas tidak aman. Disamping itu jarak terdekat tidak terpenuhi dalam proses pertukaran air ballas. Pertukaran air ballas dapat dilakukan di daerah aman yang telah ditentukan.

Meskipun tetap sebagai pilihan hanya di seluruh dunia mengaplikasikan untuk manajemen pertukaran air ballas memiliki kelemahan sendiri. Itu tidak menghilangkan sedimen di bawah tangki ballast. Oleh karena itu, organisme sedimen terpasang dapat tinggal di sistem dan kemudian menjadi penjajah. Kiri-atas air pesisir dapat tetap di tangki ballast dan mengurangi efisiensi pembersihan organisme. Penelitian menunjukkan bahwa meskipun pertukaran air ballast umumnya mengurangi kelimpahan fitoplankton, di beberapa kesempatan, konsentrasi beberapa organisme berbahaya meningkat dalam tangki ballast [5]. Pada pertukaran air ballast secara dramatis mengurangi indikator jumlah plankton taksa. Namun, proses ini kurang efektif untuk jumlah plankton. Oleh karena itu, kebutuhan menerapkan teknologi pengolahan manajemen air ballast yang efektif meningkat.

\subsection{Regulasi oleh IMO}

Pentingya standar pengolahan air ballas untuk membentuk teknologi pengolahan yang 
efektif telah ditekankan pada simposium internasional pengolahan air ballas. Pada bulan Februari 2004, "International Convention for the Control and Management of Ships Ballast Water \& Sediments" telah diadopsi oleh IMO. Konvensi berubah menjadi enter in to force setlah 12 bulan dari tanggal tersebut dan 30 negara telah menerapkannya. Hal ini merepresentasikan $35 \%$ dari tonnase pelayaran dunia.

Berdasarkan Konvensi, perlunya melaksanakan rencana khusus manajemen air ballast untuk kapal individu (Peraturan B-1) dan mempertahankan sebuah buku catatan untuk operasi terkait air ballas (Peraturan B-2). Standar perawatan yang harus dipenuhi oleh rencana manajemen air ballas kapal 'atau "standar kinerja" dijelaskan di bawah Peraturan D-2 dari Konvensi seperti dirangkum pada Tabel 2. Hal ini dapat dilihat bahwa kedua faktor kesehatan manusia dan risiko invasi biologi dianggap dalam pengembangan standar kinerja.

Tabel 2. Regulasi IMO D-2

\begin{tabular}{|c|c|}
\hline Organism & Standard \\
\hline $\begin{array}{l}\text { Toxic Vibrio cholerae (O1 } \\
\text { and O139) }\end{array}$ & $\begin{array}{l}<1 \mathrm{cfu} / 100 \mathrm{ml} \text { or; } \\
<\quad 1 \quad 1 \quad \mathrm{cfu} / 1 \mathrm{~g} \\
\text { zooplankton samples }\end{array}$ \\
\hline Escherichia Coli & $<250 \mathrm{cfu} / 100 \mathrm{ml}$ \\
\hline Intestinal Enterococci & $<100 \mathrm{cfu} / 100 \mathrm{ml}$ \\
\hline $\begin{array}{l}\geq 50 \mu \mathrm{m} \text { (minimum } \\
\text { dimension of organism) }\end{array}$ & $\begin{array}{lcc}< & 10 & \text { viable } \\
\text { organisms } / 1 \mathrm{~m}^{3} & \\
\end{array}$ \\
\hline $\begin{array}{l}10-50 \mu \mathrm{m} \text { (minimum } \\
\text { dimension of organism) }\end{array}$ & $\begin{array}{l}<10 \text { viable organisms/ } \\
1 \mathrm{ml}\end{array}$ \\
\hline
\end{tabular}

Standar ini akan digunakan sebagai pedoman untuk pengembangan rencana pengelolaan air ballas dan teknologi. Menurut Peraturan D-3 Konvensi, teknologi pengolahan air ballas harus mendapatkan persetujuan dari IMO. Dasar persetujuan adalah regulasi D-2 (yaitu standar kinerja). Pengembang teknologi harus mengatasi setiap organisme diatur di laboratorium, tanah, dan fasilitas pada kapal diuji. Efisiensi desinfeksi setiap organisme harus memenuhi standar dan data yang cukup harus disediakan.

\section{METODOLOGI PENELITIAN}

Alur metodologi penelitian seperti pada Gambar 3 dijelaskan sebagai berikut:

KAPAL, Vol. 13, No. 3 Oktober 2016
A. Tipe Penelitian

Jenis penelitian yang digunakan dalam penelitian ini adalah penelitian mengenai penerapan peraturan air ballas yang telah ditetapkan IMO dalam The International Convention for the control and management of ships ballast water and sediment's 2004 menggunakan pendekatan kepustakaan dan bahanbahan referensi lainnya yang berhubungan dengan Eksistensi peraturan mengenai ratifikasi peraturan air ballas melalui Peraturan Presiden No. 132 tahun 2015 mengenai pengesahan Konvensi internasional untuk pengendalian dan manajemen air ballas dan sedimen dari kapal 2004.

B. Pendekatan

Pendekatan yang dilakukan dalam kajian ini adalah mengenai aspek hukum, aspek teknis dan aspek ekonomis apabila Indonesia meratifikasi peraturan IMO mengenai Konvensi internasional untuk pengendalian dan manajemen air ballas dan sedimen dari kapal 2004.

C. Aspek aspek yang akan dianalisa :

a. Aspek Hukum

Dalam aspek hokum yang akan dianalisa adalah kajian teoritis mengenai The International Convention for the control and management of ships ballast water and sediment's 2004 dan pentingnya ratifikasi pengesahan Konvensi internasional untuk pengendalian dan manajemen air ballas dan sedimen dari kapal 2004 di Indonesia dan menganalisa peraturan yang mendukung maupun bertentangan serta sampai pada aspek pelaksanaannya seperti sangsi / hukuman akibat pelanggaran manajmen air ballas.

b. Aspek Teknis

Mempelajari aspek aspek teknis yang dilakukan dalam ratifikasi Konvensi internasional untuk pengendalian dan manajemen air ballas dan sedimen dari kapal 2004. Mulai dari metode primer dan sekunder yang digunakan, keuntungan dan kerugian dari masing masing metode, sampai aspek teknis pemasangan teknologi manajemen air ballas pada kapal. Adapun pemilihan teknologi yang dimaksud adalah sebagai berikut:

- Current Ballast water Treatment (BWT)

- Filtrasi 
- Pemisahan cyclonic / hydrocyclonic

- Heat Treatment / perlakuan panas

- Radiasi ultraviolet

- Kavitasi (suara ultra)

- Electrocution

- Treatment Magnetic

- Subtansi aktif

- Menggunakan multikomponen

c. Aspek Ekonomis

Dalam ratifikasi Konvensi internasional untuk pengendalian dan manajemen air ballas dan sedimen dari kapal 2004, terdapat stakeholder yang berkepentingan disini salah satunya adalah pemilik kapal, sehingga perlu dianalisa dari segi ekonomis ratifikasi peraturan ini.

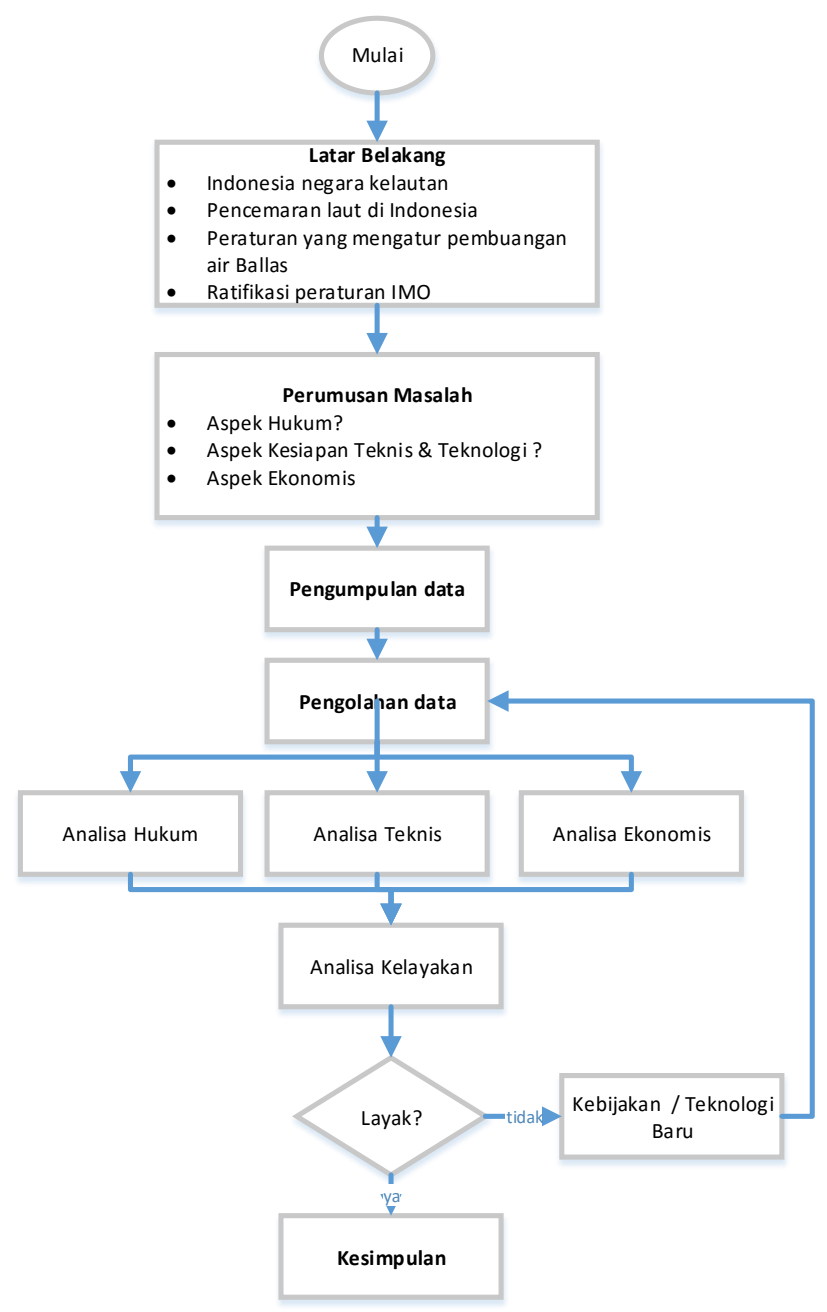

Gambar 3. Diagram alir metodologi penelitian

\section{HASIL DAN PEMBAHASAN}

\subsection{Analisa Hukum}

Air ballas yang mempunyai peran penting menjaga keseimbangan kapal dapat berfungsi sebagai vektor atau pembawa spesies asing yang berbahaya ketika air ballas tersebut dibuang di suatu area laut sehingga mengakibatkan gangguan terhadap spesies lokal atau terhadap keseimbangan ekosistem, merusak keanekaragaman hayati, menyebabkan gangguan terhadap lingkungan, kesehatan manusia, dan pemanfaatan secara ekonomi di area tersebut. Mengingat pemanfaatan laut yang begitu luas, kondisi perairan, dan ekosistem laut harus dilindungi dari kemungkinan perubahan yang merugikan.

Sebagai upaya mewujudkan perlindungan maritim, Peraturan Pemerintah Nomor 21 Tahun 2010 tentang Perlindungan Lingkungan Maritim sebagai jabaran dari Undang-Undang Nomor 17 Tahun 2008 tentang Pelayaran, telah sejalan dengan Konvensi Internasional untuk Pengendalian dan Manajemen Air Ballas dan Sedimen dari Kapal, 2004 dan Undang-Undang Nomor 17 Tahun 1985 tentang pengesahan United Nations Convention on the LAW of the Sea (UNCLOS). UNCLOS menyatakan bahwa setiap negara mempunyai hak berdaulat untuk pemanfaatan sumber-sumber kekayaan alamnya sesuai dengan kewajibannya untuk melindungi dan melestarikan lingkungan lautnya.

Sebagai bagian maritim dunia, Indonesia mempunyai kepentingan untuk menjaga kelestarian lingkungan maritimnya dengan menerapkan ketentuan Konvensi Internasional untuk Pengendalian dan Manajemen Air Ballas dan Sedimen Kapal, 2004 secara penuh. Ratifikasi konvensi tersebut memberikan kepastian hukum guna melindungi lingkungan maritim Indonesia dari HAOP (Harmful Aquatic Organism and Pathogens) atau IAS (Invasive Alien Species) akibat pembuangan air ballas. Pelaksanaan ketentuan konvensi tersebut akan memberikan penguatan terhadap upaya perlindungan lingkungan maritim Indonesia dan sebagai salah satu pihak dalam konvensi, Indonesia akan mendapat manfaat terkait penegakan hukum yang terstandar, hak berpartisipasi dalam pengajuan usulan terkait manajemen air ballas, serta kerjasama dalam pertukaran informasi mengenai riset dan inovasi teknologi baru. 


\subsection{Analisa Teknis}

Menurut regulasi D-3 pada konvesi IMO (International Maritime Organization) Ballast Water Management menyatakan bahwa sistem teknologi perlakuan air ballas harus mendapatkan persetujuan oleh negara yang bersangkutan dan teknologi yang menggunakan zat aktif harus disetujui oleh IMO [6]. Teknologi perlakuan air ballas dibedakan pada metode dan pengaplikasiannya, skalabilitas, lama waktu perlakuan air ballas (lama waktu pemusnahan dan aman untuk pembuangan), kebutuhan daya yang digunakan, efek yang ditimbulkan terhadap sistem kapal, struktur maupun terhadap lingkungan, faktor keselamatan, dan biaya untuk pemasangan serta operasional. Metode perlakuan air ballas terbagi menjadi tiga cara (Tabel 3), yakni secara mekanis (filtration dan hydroclonic separation, fisik ( $U V$ radiation dan deoxidation), dan kimiawi (ozonation, chlorination dan electrolysys). Masing-masing teknologi perlakuan air ballas tersebut memiliki karakteristik yang berbeda-beda. Dengan memperhatikan perbedaan dan batasan pada masing-masing teknologi serta mempertimbangkan ketersedian teknologi tersebut pada pasar, merupakan langkah awal untuk melakukan pemilihan teknologi perlakuan air ballas yang akan diapikasikan. Pemilihan teknologi perlakuan air ballas umumnya menggabungkan dua jenis metode, dimana metode pertama difungsikan untuk proses filtrasi (mekanis) terhadap spesies yang ukurannya lebih dari $50 \mu \mathrm{m}$ dan metode kedua difungsikan untuk perlakuan terhadap spesies yang lebih kecil dan juga berfungsi sebagai disinfektan. Disinfektan dapat menggunakan teknologi kimiawi maupun teknologi yang bersifat fisik.

Tabel 3. Teknologi perlakuan air ballas

\begin{tabular}{|c|c|c|c|}
\hline $\begin{array}{c}\text { Teknologi Perlakuan } \\
\text { Air Ballas }\end{array}$ & Operasional & Keamanan & Lingkungan \\
\hline \multirow{3}{*}{ Filtration } & Treatment saat: pengambilan; & \multirow{3}{*}{ Tidak ada efek yang ditimbulkan. } & Pengurangan sedimen ke dalam tangki \\
\hline & Waktu pemusnahan: saat treatment; & & ballas; \\
\hline & Penurunan tekanan dan laju aliran berkurang. & & Tidak efektif untuk mikro organisme. \\
\hline \multirow[b]{2}{*}{ Cyclonic } & Treatment saat: pengambilan; & \multirow{4}{*}{ Tidak ada efek yang ditimbulkan. } & Pengurangan sedimen ke dalam tangki \\
\hline & Waktu pemusnahan: saat treatment; & & ballas; \\
\hline \multirow{2}{*}{ separation } & Penurunan tekanan dan laju aliran berkurang; & & Tidak efektif untuk mikro organisme. \\
\hline & Biaya Pemeliharaan minimum. & & \\
\hline Coagulation/ & Treatment saat: pengambilan; & \multirow{3}{*}{ N/a. } & Pengurangan sedimen ke dalam tangki \\
\hline \multirow[t]{2}{*}{ flocculation } & Waktu pemusnahan: $\mathrm{n} / \mathrm{a}$; & & ballas; \\
\hline & Perlunya tangki penyimpanan untuk bahan tambahan. & & Tidak efektif untuk mikro organisme. \\
\hline \multirow{4}{*}{ UV } & Treatment saat: pengambilan dan pembuangan; & & \\
\hline & Waktu pemusnahan: saat treatment; & Pemaparan sinar UV dapat & Efisiensi tergantung pada kualitas air; \\
\hline & Konsumsi energi bertambah; & membahayakan. & Efektif untuk mikro organisme. \\
\hline & Biaya pemeliharaan tinggi. & & \\
\hline \multirow{4}{*}{ Ozonation } & Treatment saat: umumnya saat pengambilan; & Racun (hal ini utamanya mengiritasi, & Efektif untuk mikro organisme; \\
\hline & systems and at discharge for others; & khususnya memberikan efek terhada & Netralisasi air ballas sebelum dibuang; \\
\hline & Waktu pemusnahan: sampai dengan $15 \mathrm{jam;}$ & mata dan sistem pernapasan). & Efisiensi tergantung pada kualitas air; \\
\hline & Kemungkinan adanya korosi terhadap tangki dan pipa. & & Polusi udara. \\
\hline & Treatment saat: pengambilan; & Risiko terhadap pemaparan kimiawi & \\
\hline Electrolytic & Waktu pemusnahan: saat treatment; & pada kru kapal; & Efektif untuk berbagai organisme; \\
\hline chlorination/ & Kemungkinan adanya korosi terhadap tangki dan pipa; & Pembuangan gas hidrogen dan & Netralisasi air ballas sebelum dibuang; \\
\hline \multirow[t]{2}{*}{ electrolysis } & Konsumsi energi bertambah; & gas klorinasi yang dihasilkan & Efisiensi tergantung pada kualitas air. \\
\hline & Biaya pemeliharaan tinggi. & oleh elektrolisis. & \\
\hline
\end{tabular}

Sumber: Tang et al. 2006; Sutherland et al. 2001; Sateikiene, Januteniene 2012. [7] 
Pada saat ini ada berbagai macam teknologi perlakuan air ballas yang dikembangkan oleh masing-masing negara di dunia. Diantara banyaknya teknologi, yang menggunakan zat aktif merupakan teknologi yang memberikan informasi yang terpercaya berdasarkan laporan penilaiannya, Tabel 4. Kategori dan perbandingan sistem teknologi perlakuan air ballas

\begin{tabular}{|c|c|c|c|}
\hline No & Teknik Perlakuan Air Ballas & Pabrik & Keterangan \\
\hline 1 & Electrolysis + & Techross & - Tidak perlu membawa bahan kimia \\
\hline 2 & Filter + Electrolysis & EctoSys, RBT, GreenShip & - Tidak perlu membawa bahan kimia \\
\hline \multirow{2}{*}{3} & Filter + Electrolysis, & Meyer & \multirow{2}{*}{ Chemical } \\
\cline { 3 - 4 } & Injection+ Neutralizer & Severn, Mitsubish, Electrichor & - Tidak perlu membawa bahan kimia \\
\hline 4 & Filter + Electrolysis + & OceanSaver, & - Tidak perlu membawa bahan kimia \\
\hline 5 & Inert Gas Filling & NEl & - Jumlah produk sisa sedikit \\
\hline \multirow{2}{*}{6} & Filter + AOT & PureBallast & - Tidak perlu membawa bahan kimia \\
\hline 7 & Filter + UV & Panasia, OptiMarin, Gauss, & - Jumlah produk sisa sedikit \\
\cline { 3 - 4 } & Filter + Ozone & Marenco, Willand & - Tidak perlu membawa bahan kimia \\
\hline 9 & Filter + Chlorine Dioxide & Special Pipe, NK & - Tidak perlu membawa bahan kimia \\
\hline 9 & Filter + Chemical & EcoChlor & - Tingkat performa tinggi \\
\hline 10 & Flocculation + Filter & Peraclean & - Biaya investasi awal rendah \\
\hline
\end{tabular}

Dengan melihat kondisi lingkungan perairan Indonesia serta mempertimbangkan berbagai aspek, pemilihan teknologi perlakuan air ballas dilakukan dengan metode pembobotan (scoring). Dimana skor 1 sampai 4 merupakan skor untuk nilai paling rendah dan paling tinggi. Adapun

Tabel 5. Skor untuk masing-masing sistem

\begin{tabular}{|c|c|c|c|c|c|c|c|c|c|c|c|}
\hline Pertimbangan & Bobot & Skor (1) & Skor (2) & Skor (3) & Skor (4) & Skor (5) & Skor (6) & Skor (7) & Skor (8) & Skor (9) & Skor (10) \\
\hline Efisiensi Pemusnahan & 0,157 & 3 & 4 & 4 & 4 & 4 & 4 & 4 & 4 & 4 & 3 \\
\hline Jejak Mudah Hilang & 0,066 & 3 & 4 & 4 & 3 & 3 & 4 & 3 & 3 & 3 & 3 \\
\hline $\begin{array}{c}\text { Kesederhanaan Sistem } \\
\text { Keamanan terhadap Kru } \\
\text { Kapal }\end{array}$ & 0,169 & 3 & 3 & 3 & 3 & 3 & 3 & 3 & 3 & 3 & 3 \\
\hline $\begin{array}{c}\text { Ramah Lingkungan } \\
\text { Total }\end{array}$ & 0,143 & 3 & 3 & 3 & 3 & 3 & 3 & 3 & 3 & 3 & 3 \\
\hline
\end{tabular}

yang mana hal ini memfasilitasi untuk teknis evaluasi yang terpercaya [8]. Berikut pada Tabel 4 merupakan macam-macam sistem teknologi perlakuan air ballas menurut Korean Register of Shipping: 
Tabel 6. Hasil penilaian sistem teknologi perlakuan air ballas

\begin{tabular}{|c|c|c|c|c|c|c|c|c|c|c|c|}
\hline Pertimbangan & Bobot & $\begin{array}{c}\text { Penilaian } \\
(\mathbf{1}\end{array}$ & $\begin{array}{c}\text { Penilaian } \\
(\mathbf{2})\end{array}$ & $\begin{array}{c}\text { Penilaian } \\
\mathbf{( 3 )}\end{array}$ & $\begin{array}{c}\text { Penilaian } \\
(\mathbf{4})\end{array}$ & $\begin{array}{c}\text { Penilaian } \\
\mathbf{( 5 )}\end{array}$ & $\begin{array}{c}\text { Penilaian } \\
(\mathbf{6})\end{array}$ & $\begin{array}{c}\text { Penilaian } \\
\mathbf{( 7 )}\end{array}$ & $\begin{array}{c}\text { Penilaian } \\
\mathbf{( 8 )}\end{array}$ & $\begin{array}{c}\text { Penilaian } \\
(\mathbf{9})\end{array}$ & $\begin{array}{c}\text { Penilaian } \\
(\mathbf{1 0})\end{array}$ \\
\hline Efisiensi Pemusnahan & 0,157 & 0,012 & 0,017 & 0,017 & 0,017 & 0,017 & 0,017 & 0,017 & 0,017 & 0,017 & 0,012 \\
\hline Jejak Mudah Hilang & 0,066 & 0,006 & 0,008 & 0,008 & 0,006 & 0,006 & 0,008 & 0,006 & 0,006 & 0,006 & 0,006 \\
\hline Kesederhanaan Sistem & 0,169 & 0,017 & 0,017 & 0,017 & 0,017 & 0,017 & 0,017 & 0,017 & 0,017 & 0,017 & 0,017 \\
\hline $\begin{array}{c}\text { Keamanan terhadap Kru } \\
\text { Kapal }\end{array}$ & 0,255 & 0,026 & 0,026 & 0,026 & 0,026 & 0,026 & 0,026 & 0,026 & 0,026 & 0,026 & 0,026 \\
\hline Ramah Lingkungan & 0,143 & 0,013 & 0,017 & 0,017 & 0,013 & 0,013 & 0,017 & 0,017 & 0,013 & 0,013 & 0,013 \\
\hline Total & 1 & 0,073 & 0,084 & 0,084 & 0,078 & 0,078 & 0,084 & 0,082 & 0,078 & 0,078 & 0,073 \\
\hline
\end{tabular}

Dari hasil pembobotan (scoring) pada masingmasing sistem menunjukkan bahwa ada tiga sistem dengan perolehan skor tertinggi yakni pada sistem ke-2 (filter + electrolysis), sistem ke-3 (filter + electrolysis + chemical injection + neutralizer), dan sistem ke-6 (filter + UV). Dari ketiga jenis sistem ini akan dilakukan analisis ekonomis untuk mengetahui sistem yang paling efektif dan efisien selain terhadap aspek teknis yang telah dianalisa.

\subsection{Analisa Ekonomis}

Selain aspek teknis yang dianalisis untuk pemilihan sistem teknologi perlakuan air ballas, juga harus mempertimbangkan pada aspek ekonomis. Analisis ekonomis dilakukan dengan menganalisa biaya instalasi dan operasional masing-masing sistem dengan merujuk pada pihak industri pembuat sistem teknologi tersebut.

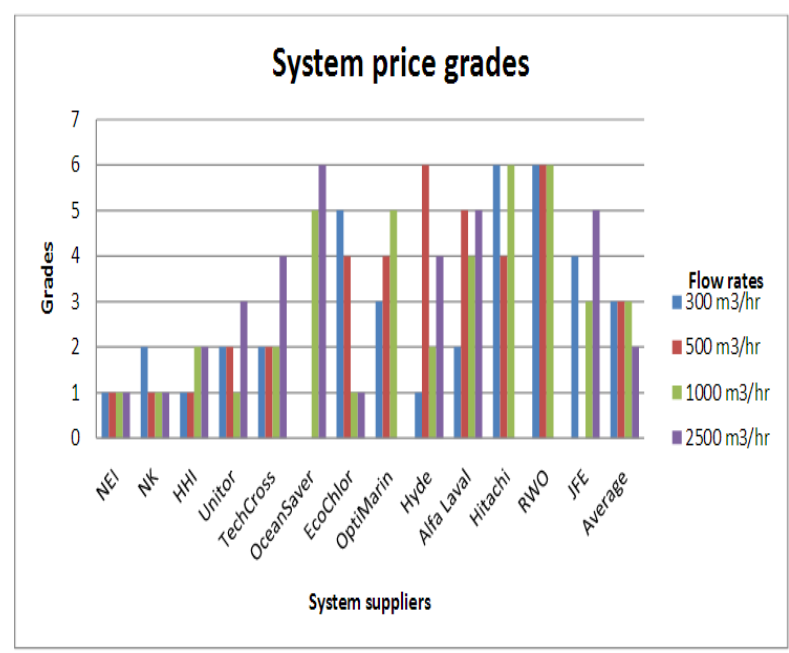

Analisis ekonomis dilakukan dengan membandingkan data biaya instalasi pada masingmasing pabrikan. Dari data diatas ditunjukkan batasan nilai 1 sampai 6 . Nilai 1 adalah sistem dengan biaya paling rendah dan 6 adalah sistem dengan biaya paling tinggi. Dengan melihat sistem yang mempunyai skor pembobotan paling tinggi ( lihat 4.2 Analisa Teknis) serta meninjau biaya instalasi pada masing-masing pabrikan, didapatkan bahwa sistem ke-2 (filter + electrolysis) dengan pabrikan RBT (Resource Ballast Technology)/ Unitor BWTS merupakan sistem dengan biaya yang paling rendah. Sehingga dari analisis ekonomis didapatkan kesimpulan bahwa sistem perlakuan air ballas yang cocok digunakan untuk perairan Indonesia adalah Filter + Electrolysis dengan pabrikan Unitor BWTS.

\section{KESIMPULAN DAN SARAN}

\subsection{Kesimpulan}

Setelah dilakukan penelitian, disimpulkan bahwa:

1. Peraturan Pemerintah Nomor 21 Tahun 2010 tentang Perlindungan Lingkungan Maritim sebagai jabaran dari UndangUndang Nomor 17 Tahun 2008 tentang Pelayaran, telah sejalan dengan Konvensi Internasional untuk Pengendalian dan Manajemen Air Ballas dan Sedimen dari Kapal, 2004 dan Undang-Undang Nomor 17 Tahun 1985 tentang pengesahan United Nations Convention on the LAW of the Sea (UNCLOS). 
2. Penggunaan sistem manajemen air ballas untuk kapal di perairan Indonesia lebih efektif dan efisien menggunakan filtration + electrolysis dengan RBT (Resource Ballast Technology)/ Unitor BWTS sebagai supplier.

\subsection{Saran}

Adapun saran untuk penelitian ini adalah:

1. Perlu adanya penambahan sampel air ballas di beberapa perairan Indonesia untuk penelitian yang lebih lanjut

\section{DAFTAR PUSTAKA}

[1] Ruiz, G.M., P.W. Fofonoff, J.T. Carlton, M.J Wonham, and A.H Hines. "Invasion of coastal marine communities in North America: Apparent patterns, processes, and biases." Annual review of ecology and systematics, 2000 a.: 31, 481-531.

[2] L. Monplaisir, Collaborative Engineering for Product Design and Development, California, USA: American Scientific Publishers, 2002.

[3] J. E. Monzon, "The cultural approach to telemedicine in Latin American homes (Published Conference Proceedings style)," in Proc. 3rd Conf. Information Technology Applications in Biomedicine, ITAB'00, Arlington, VA, pp. 50-53.

[4] http://globallast.imo.org

[5] Taylor, M.D., L.M. MacKenzie, T.J.

Dodgshun, G.A. Hopkins, E.J. de Zwart, and Hunt. "Trans-pacific shipboard trials on planktonic communities as indicators of open ocean ballast water exchange." Marine ecology progress series, 2007: 350, 41-54. 